\title{
Bacterial Biomass Effect on Performance Improving of Vertical Flow Constructed Wetlands for Domestic Wastewater Treatment
}

\author{
Franck Michael ZAHUI ( $\nabla$ zahui_franck@yahoo.fr) \\ University of Man, Ivory Coast https://orcid.org/0000-0002-9203-2370 \\ Jean-Marie Pétémanagnan Ouattara \\ University of Man, Ivory Coast \\ Mahamadou Kamagaté \\ University of Man \\ Lacina Coulibaly \\ University of Man, Ivory Coast
}

\section{Research Article}

Keywords: Constructed wetlands, domestic wastewater, plant species, bacterial density, removal efficiency.

Posted Date: May 17th, 2021

DOI: https://doi.org/10.21203/rs.3.rs-507260/v1

License: (c) This work is licensed under a Creative Commons Attribution 4.0 International License. Read Full License 


\section{Abstract}

Bacteria are frequently studied in constructed wetlands (CWs) due to their effective involvement in pollutants purification processes. In this study, aerobic, anaerobic and total bacteria densities and their vertical distribution profile within pilot-scale vertical flow CWs planted with different plant species were investigated. Five beds were planted in monoculture with Andropogon gayanus, Chrysopogon zizanioides, Echinochloa pyramidalis, Pennisetum purpureum and Tripsacum laxum, and one unplanted bed was used as control. At the end of the treatment trial, bacteria were collected by taking cores of sediment samples at the corners and the center of each bed following six layers in the vertical profile. In fact, the presence of plants on CWs improved the bacterial density and removal efficiencies in the system, with yields from 5.9 to $24.1 \%$ regardless the pollutant. However, few anaerobic bacteria were obtained in the different wetlands, and unable to reduce $\mathrm{NO}_{3}{ }^{-}$, excluding for beds planted with T. laxum and P. purpureum. Besides, the number of aerobic bacteria determined decreased (i.e., 17.4 $10^{6}$ to $0.110^{6} \mathrm{CFU} . \mathrm{g}^{-1}$ ), while that of anaerobic bacteria increased (i.e., $0.110^{6}$ to $2.110^{6} \mathrm{CFU} . \mathrm{g}^{-1}$ ) from the upper to the bottom layers in the planted beds. Otherwise, anaerobic bacteria were more abundant in the control than in planted beds. Then, total bacteria were dominated by aerobic bacteria, and decreased from surface toward the bottom. As $P$ purpureum promotes the best performance, $\mathrm{CWs}$ with this type of plant could be a cost-effective alternative method of treating wastewater.

\section{Introduction}

Constructed wetlands (CWs) are engineered systems, designed and constructed to use the natural functions of wetland vegetation, soils and their microbial populations to purify wastewater (Vymazal 2010; Alexandros and Akratos 2016; Dotro et al. 2017). This technology requires little energy and offers a sustainable solution to wastewater purifying. However, CWs have generally low installation and operating costs, easy of use, and good landscape integration and efficiency comparable to active systems (Dotro et al. 2017).

The CWs process has two essential variants according to the water flow direction (i.e., horizontal and vertical). In the horizontal systems, oxygen concentrations are limited (Nivala et al. 2013) while those of vertical flow are unsaturated, and operate under a predominantly aerobic regime. Moreover, the use of vertical-flow $\mathrm{CWs}$ reduces environmental risks such as the release of odors and methane and the proliferation of mosquitoes (Mander et al. 2005). It increases oxygen transfer rate, improves nitrification process, and promotes the oxidation capacity of organic matter (Vymazal 2007).

Unlike most treatment processes that focus on a single treatment mechanism or a type of pollutant, CWs use several synergic processes to simultaneously remove the multipollutants. Indeed, these processes are physical, chemical and biological such as sedimentation, precipitation, adsorption, plant uptake, biological changes by microorganisms (Choudhary et al. 2011). These mechanisms are related via the main components of the system, namely plants, sediments and microorganisms living in sediments (Stottmeister et al. 2003). These microorganisms play an important role within the process upon the removal of pollutants.

According to Oehl et al. (2004), Tao et al. (2007), Vymazal (2007), Richardson and Simpson (2011) and Wu et al. (2011, 2013), the microbial processes within CWs are one of the major mechanisms for removing some pollutants (nitrogen and organic matter). They develop naturally in the bed sediments, and are mainly depend on hydraulic conditions, wastewater properties, including substrate (sediment), and nutrient quality and availability, plants, and different environmental factors such as oxygen level, $\mathrm{pH}$ and temperature (Stottmeister et al. 2003; Truu et al. 2009). In fact, many microorganisms live within the CWs, including bacteria, algae, fungi, protozoa, zooplankton, viruses and nematodes (Weber and Gagnon 2014; Wang et al. 2016). However, the most frequently reported studies focus on bacteria, due to their effective involvement in purification processes (Tao et al. 2007; Puigagut et al. 2007; Truu et al. 2009). According to different type of bacteria species, they decompose, transform or assimilate wastewater pollutants into aerobic or anaerobic conditions in the CWs sediments.

To our knowledge, the vertical distribution of bacterial flora as a function of different depths within $\mathrm{CW}$ has never been investigated to date. Thus, this vertical profile study of these bacteria could help us to assess the CW performances, and insights understand the purification mechanisms of the pollutants that take place there.

The aim of this study was to examine aerobic, anaerobic and total bacteria densities and their vertical distribution profile within pilot-scale vertical flow CWs planted with different plant species (i.e.,Andropogon gayanus, Chrysopogon zizanioides, Echinochloa pyramidalis, Pennisetum purpureum and Tripsacum laxum) in monoculture. Specifically, it's about determining, on the one hand, the CW removal efficiency, and on the other hand, the densities of aerobic, anaerobic and total bacteria from the upper surface to the bottom layer of the beds sediments.

\section{Materials And Methods}




\subsection{Materials}

All the chemicals were purchased from Sigma Aldrich (France), and having high purity analytical properties. The chemicals and their concentrations used in this study were denoted in Table 1.

\subsection{Methods}

\subsubsection{Experimental Set-up}

The pilot was built with cement in the form of rectangular beds (i.e., length $=1.45 \mathrm{~m}$, wide $=1.00 \mathrm{~m}$, depth $=0.60 \mathrm{~m}$ and area of $1.45 \mathrm{~m}^{2}$ ) (Figure 1), according to the description of Coulibaly et al. (2008a, b). The beds were filled from bottom to the top with $0.1 \mathrm{~m}$ gravel (5/15 $\mathrm{mm}$ ) covered with cloth and $0.6 \mathrm{~m}$ white lagoon sand (mean sand diameter $=572 \mu \mathrm{m}$, uniformity coefficient $=0.4$, porosity $=37.5 \%$ ), previously washed to remove clay, loam and organic matter. Each bed was equipped with irrigation devices consisted of 6 Polyvinyl Chloride (PVC) pipes (length: $1.45 \mathrm{~m}$; diameter; $0.008 \mathrm{~m}$ ) containing 60 lateral holes (See Figure 1) to allow homogenous distribution of effluent on its surface. The bed slope was $1 \%$ oriented via PVC of $0.032 \mathrm{~m}$ diameter to drain out the effluent of bed. Treated water was collected at the beds' exit using tanks ( $100 \mathrm{~L}$ ) thus to quantify it. The experiment was performed during seven (7) months from February to August 2017 on a pilot-scale located at NANGUI ABROGOUA University (Abidjan, Côte d'Ivoire). This zone is characterized by a humid tropical climate with an average temperature around $25^{\circ} \mathrm{C}$. The analyses were carried out both within the Laboratory of Environment and Aquatic Biology of NANGUI ABROGOUA University and the National Laboratory for Quality Assurance Testing, Metrology and Analysis of Côte d'Ivoire.

\subsubsection{Plant selection}

Five (5) plants were selected and collected in different region of Côte d'Ivoire for this study such as Andropogon gayanus (Kunth, 1833), Chrysopogon zizanioides (Roberty, 1960), Echinochloa pyramidalis (Lam.) Hitchc. \& Chase (1917), Pennisetum purpureum (Schumach. 1827) and Tripsacum laxum (Nash, 1909) due to the economic interest of their biomass. Indeed, these plants are highly appreciated by agro-pastoralists, and also propitious to the Côte d'Ivoire climatic conditions. In addition to having a positive impact on wastewater treatment, they could generate further revenues that can support maintenance costs.

\subsubsection{Synthetic domestic wastewater}

Synthetic domestic wastewater was used in this study to avoid CWs clogging problems reported by Coulibaly et al. (2008a, b) and Ouattara et al. (2008), and minimize the fluctuation of pollutant concentrations in real wastewater used during each experiment. The composition of synthetic domestic wastewater was carried according to Rodgers et al. (2006), Healy et al. (2010) and Metcalf and Eddy (1991) methods. However, some modifications were done in order to respect the characteristics (i.e. nitrogen (N), phosphorus (P) and carbon (C) concentrations) of domestic wastewater encountered in developing countries. The composition of the synthetic domestic wastewater used, was Chemical Oxygen Demand (COD), 5 day-Biochemical Oxygen Demand $\left(\mathrm{BOD}_{5}\right)$, Total Nitrogen (TN), Total Suspended Solids (TSS), Total Phosphorus (TP), with COD $=628 \mathrm{mg} \mathrm{O}_{2} \cdot \mathrm{L}^{-1}, \mathrm{BOD}_{5}=380 \mathrm{mg} \mathrm{O} \mathrm{L}^{-1}, \mathrm{TN}=45 \mathrm{mg} \cdot \mathrm{L}^{-1}, \mathrm{TSS}=300 \mathrm{mg} \cdot \mathrm{L}^{-1}, \mathrm{TP}=12 \mathrm{mg} \cdot \mathrm{L}^{-1}, \mathrm{pH}=6.7-8$.

\subsubsection{Editing and experimental tests}

Five (5) beds were planted with the plant seedlings (i.e., 9 plants $\mathrm{m}^{-2}$ ) spaced of $40 \mathrm{~cm} \times 40 \mathrm{~cm}$ in monoculture and the sixth remained an unplanted control. These young plants were collected from nurseries established near the experimental pilot, and previously cut to $20 \mathrm{~cm}$ above the roots before bed's planting. Then, the planted beds were fed with tap water for one month to allow acclimatize. After the acclimation period, each bed was intermittently fed (3 days/week) with $23.64 \times 10^{-3} \mathrm{~m} \cdot \mathrm{d}^{-1}$ hydraulic loading of synthetic domestic wastewater over 6 months. The synthetic domestic wastewater tank was cleaned before and after feeding of beds to remove all the impurities settled. During the experiments, water samples of bed exits were collected each week, stored within an ethylene bottle at $4{ }^{\circ} \mathrm{C}$ to analysis. Finally, 24 samples were taken in each bed during the duration of the experiment. The growth response of the tested plant species was determined from stumps diameter and above-ground biomass of plants according to Ouattara et al. (2008). In fact, the plant aboveground biomass produced was harvested and weighed at the end of each two-month growth cycle as well as the plants stumps diameters measurement during the experiment. For the bed microfauna study, sampling consisted of a collection of sediments at the end of the treatment trial. This was performed in six sediment layers in the vertical profile, ranging from upper surface to the bottom of the beds as following: [0; $10 \mathrm{~cm}],[10 ; 20 \mathrm{~cm}],[20 ; 30 \mathrm{~cm}],[30 ; 40 \mathrm{~cm}],[40 ; 50 \mathrm{~cm}]$ and [50; $60 \mathrm{~cm}]$.

\subsubsection{Analysis methods and removal efficiency}


Different methods were used to analyze all the parameters in three duplications. $\mathrm{pH}$ and Dissolved Oxygen (DO) were determined according to ISO 10523 (2008) and ISO 5814 (2012), respectively. Then, Chemical Oxygen Demand (COD), 5 day-Biochemical Oxygen Demand $\left(\mathrm{BOD}_{5}\right)$, Total Nitrogen $(\mathrm{TN})$, ammonium $\left(\mathrm{NH}_{4}{ }^{+}\right)$, nitrate $\left(\mathrm{NO}_{3}{ }^{-}\right)$and orthophosphate $\left(\mathrm{PO}_{4}{ }^{3-}\right)$ were also determined according to ISO 6060/2 (1989), ISO 5815/1 (2003), ISO 5663 (1984), ISO 7150/1 (1984), ISO 7890/3 (1988) and ISO 6878 (2004), respectively. Finally, removal efficiencies of all the parameters above-mentioned was calculated following Equation 1:

Removal efficiency $(\%)=\frac{C_{i} V_{i}-C_{e} V_{e}}{C_{i} V_{i}} \times 100$

Where $C_{i}$ and $C_{e}$ are the influent and effluent concentrations $\left(m g \cdot L^{-1}\right), V_{i}$ and $V_{e}$ are the influent and effluent volume $(L)$ in the CWs.

\subsubsection{Sediment sampling and microbial biomass analysis}

Sediment sampling for bacteria analysis was performed by coring with PVC pipe ( $\Phi=16 \mathrm{~mm})$. According to Puigagut et al. (2007), the surface of the beds was divided into three (3) equal sections for a better taken account of the bacteria distribution within the beds. In each section, three sampling points (one at each extremity of the bed, and one at the center) were uniformly distributed over the width of the reactors from which a composite sample of the sediment layer under consideration was formed. Thus, the samples were stored in jars at $2^{\circ} \mathrm{C}$ to analysis.

The analysis of the bacteria was carried out according to the technique of germs inoculation in Plate Count Agar (PCA) (Sirianuntapiboon and Jitvimolnimit 2007). In fact, $5 \mathrm{~g}$ of the substrate sample were suspended in a sterile saline solution $(0.85 \% \mathrm{NaCl})$ of $50 \mathrm{~mL}$ and inoculated in triplicate onto PCA after stirring and sedimentation at room temperature. The aerobic germs were grown in a single layer of agar, whereas the anaerobic germs were within a double layer of agar. These germs were incubated at $37^{\circ} \mathrm{C}$ for $48 \mathrm{~h}$, and then the number of colonies formed were counted according to the international standard ISO 6222 (1999). The total number of bacteria in each sample was determined by adding the numbers of aerobic and anaerobic bacteria.

\subsubsection{Statistical analysis}

All statistical tests were performed using R studio 3.3.2 software (Ihaka and Gentleman 1996), including Kruskal-Wallis, Mann Whitney, ANOVA variances, and T-test after Shapiro-Wilk normality test.

\section{Results}

\subsection{Plant growth response and wastewater treatment in CWs}

\subsubsection{Plant growth response}

The mean of above-ground biomass and stump diameter of plant species produced onto the CWs are denoted in table 2. Overall, aboveground biomass of the plants ranged from $1.8 \pm 0.7$ to $15.2 \pm 0.7 \mathrm{~kg} \cdot \mathrm{m}^{-2}$, while their stump diameters varied from $8.6 \pm 3.6$ to $21.3 \pm 9.5$ $\mathrm{cm}$. Indeed, above-ground biomasses were classified in this order following the plants: P. purpureum $\left(15.2 \mathrm{~kg} \cdot \mathrm{m}^{-2}\right)>T$. laxum $\left(13.1 \mathrm{~kg} \cdot \mathrm{m}^{-2}\right)$ $>$ E. pyramidalis $\left(8.3 \mathrm{~kg} \cdot \mathrm{m}^{-2}\right)>$ A. gayanus $\left(2.6 \mathrm{~kg} \cdot \mathrm{m}^{-2}\right)>C$. zizanioides $\left(1.8 \mathrm{~kg} \cdot \mathrm{m}^{-2}\right)$. However, Mann Whitney test $(\mathrm{p}<0.05)$ showed that the biomasses developed by E. pyramidalis, P. purpureum and T. laxum were significantly higher than those of $A$. gayanus and $C$. zizanioides. Unlike above-ground biomasses, the sequence mean values of diameter stumps was in this order: $P$. purpureum $(21.3 \mathrm{~cm})>T$. laxum $(16.4$ $\mathrm{cm})>$ E. pyramidalis $(12.1 \mathrm{~cm})>$ C. zizanioides $(10.7 \mathrm{~cm})>A$. gayanus $(8.7 \mathrm{~cm})$. However, no significant difference observed between the diameters of the different plant stumps (ANOVA test: $\mathrm{p}>0.05$ ). Although the stump diameter of $C$ zizanioides was higher than that of $A$ gayanus, it developed the lowest above-ground biomass.

\subsubsection{Wastewater treatment in CWs}

\subsubsection{Assessment of physical parameters}

The mean values of $\mathrm{pH}$, dissolver oxygen (DO) and water volume at the inlet and outlet of all the beds (planted and unplanted) are denoted in table 3. As for $\mathrm{pH}$, values obtained in the bed outlets were higher than those of the raw water. Moreover, the average $\mathrm{pH}$ values of the planted bed exits (between 6.92 and 7.17) were slightly lower than those of the unplanted bed (7.33). However, the sequence of $\mathrm{pH}$ mean values were between raw water and unplanted bed was ranked as decreasing in this order: wastewater $\mathrm{pH}(6.81)<\mathrm{pH}($. gayanus $)(6.92)<$ 
$\mathrm{pH}$ (E. pyramidalis) (6.93) < $\mathrm{pH}$ (C. zizanioides) (7.05) < $\mathrm{pH}($ P. purpureum) $(7.06)<\mathrm{pH}($ T. laxum) $(7.17)<\mathrm{pH}($ unplanted $)(7.32)$. Besides, significant differences were observed between wastewater $\mathrm{pH}$ and those of planted beds, as well as those of the different beds between them (Mann Whitney test: $\mathrm{p}<0.05)$.

DO values measured outlet the beds (i.e., $5.41 \pm 0.9$ and $7.53 \pm 1.6 \mathrm{mg} . \mathrm{L}^{-1}$ ) were high compared with that of raw water (inlet) (i.e., $2.13 \pm 0.6$ $\left.\mathrm{mg} \cdot \mathrm{L}^{-1}\right)$, whereas those of the planted beds were greater than those of the unplanted bed. However, some significant differences were noted among those of the planted beds (Mann Whitney test: $P<0.05)$.

As for the water volume collected at the outlet of the beds, this remain less than that of wastewater applied (80 liters). Indeed, the average water volume collected in the unplanted bed $(72.4 \pm 1.9 \mathrm{~L})$ was the highest and was followed by those of the different beds planted with $\mathrm{C}$. zizanioides $(62.2 \pm 3.6 \mathrm{~L})$, A. gayanus $(60.3 \pm 3 \mathrm{~L})$, E. pyramidalis $(58.6 \pm 5.8 \mathrm{~L})$, T. laxum $(55.6 \pm 3.8 \mathrm{~L})$ and P. purpureum $(54.2 \pm 4.3 \mathrm{~L})$. Using ANOVA ( $<$ 0.05), we observed significant difference between the unplanted bed and the planted beds, while those of the beds planted with $P$ purpureum and T. laxum were of the same order of magnitude and significantly lower than water volume collected at the outlet of the other planted beds.

\subsubsection{Removal efficiencies for chemical parameters}

Table 4 showed inlet and outlet mean concentrations as well as removal efficiencies of CWs for different parameters such as COD, BOD 5 , $\mathrm{TN}, \mathrm{NH}_{4}{ }^{+}, \mathrm{NO}_{3}{ }^{-}$and $\mathrm{PO}_{4}{ }^{3-}$. In fact during the experimental tests, the concentrations of these pollutants in synthetic wastewater varied of 535-623.3 $\mathrm{mgO}_{2} \cdot \mathrm{L}^{-1}(\mathrm{COD}), 356.1-373.8 \mathrm{mgO}_{2} \cdot \mathrm{L}^{-1}\left(\mathrm{BOD}_{5}\right), 37.6-44.5 \mathrm{mg} \cdot \mathrm{L}^{-1}(\mathrm{TN}), 31-35 \mathrm{mg}^{-1}\left(\mathrm{NH}_{4}^{+}\right), 1.1-1.97 \mathrm{mg}^{-1} \mathrm{~L}^{-1}\left(\mathrm{NO}_{3}{ }^{-}\right)$and $6.8-7.9$ $\mathrm{mg} . \mathrm{L}^{-1}\left(\mathrm{PO}_{4}{ }^{3-}\right)$, with average values matching to $611.8 \mathrm{mgO}_{2} \mathrm{~L}^{-1}, 369.8 \mathrm{mgO}_{2} \cdot \mathrm{L}^{-1}, 41.4 \mathrm{mg} \cdot \mathrm{L}^{-1}, 33.4 \mathrm{mg} \cdot \mathrm{L}^{-1}, 1.8 \mathrm{mg} \cdot \mathrm{L}^{-1}$ and $7.4 \mathrm{mg} \cdot \mathrm{L}^{-1}$,

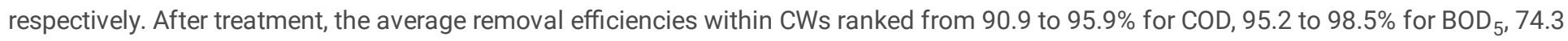
to $84 \%$ for $\mathrm{TN}, 76$ to $84 \%$ for $\mathrm{NH}_{4}{ }^{+}, 77.4$ to $96.9 \%$ for $\mathrm{PO}_{4}{ }^{3}$, regardless of the planted beds. Otherwise, the average removal efficiencies varied from 53.3 to $89.3 \%$ within unplanted beds, regardless of the parameter. We noted that the presence of the plants onto the CWs improved its yields from 5.9 to $24.1 \%$ whatever the pollutant. It is worthy that some negative values were obtained for $\mathrm{NO}_{3}{ }^{-}$in the case of $A$. gayanus, $C$. zizanioides and E. pyramidalis beds. Thus, the $C W$ s removal efficiencies were ranked following order of performance: $(P$. purpureum $)>($ T. laxum $)>($ E. pyramidalis $)>($ A. gayanus $)>($ C. zizanioides $)>$ (unplanted). However, the planted beds were significantly efficient than the unplanted beds (Mann Whitney test: $\mathrm{p}<0.05)$. Moreover, the beds with $P$. purpureum and T. laxum were more significantly efficient than those of E. pyramidalis, A. gayanus and $C$. zizanioides (Kruskal-Wallis test, $\mathrm{p} \otimes 0.05$ ).

\subsubsection{Estimation of bacterial density in $\mathrm{CWs}$}

Aerobic and anaerobic bacteria densities were assessed in the beds' sediments (Figure 2). Overall, aerobic bacteria density was higher than that of anaerobic bacteria in all the CWs beds, excluding unplanted bed. Regarding to aerobic bacteria (Figure. 2A), the median density was ranked in this order according to plants: P. purpureum $\left(7.710^{6} \mathrm{CFU} . \mathrm{g}^{-1}\right)>$ T. laxum $\left(6.410^{6} \mathrm{CFU} . \mathrm{g}^{-1}\right)>$ E. pyramidalis $\left(4.810^{6} \mathrm{CFU} . \mathrm{g}^{-1}\right)>$ A. gayanus $\left(4.510^{6} \mathrm{CFU}^{-1}{ }^{-1}\right)>$ C. zizanioides $\left(2.410^{6} \mathrm{CFU} . \mathrm{g}^{-1}\right)>$ Unplanted bed $\left(1.410^{6} \mathrm{CFU}^{-g^{-1}}\right)$. Indeed, a significant difference was observed between the bed planted with $C$. zizanioides and the other beds showing no difference between them (Mann Whitney test: $\mathrm{p}<$ 0.05).

For anaerobic bacteria in the bed sediment (Figure 2B), no difference was observed between all beds (Mann Whitney test: $p>0.05$ ), regardless the planted bed or not. Thus, anaerobic bacteria number ranged generally from $0.310^{6}$ to $210^{6} \mathrm{CFU} . \mathrm{g}^{-1}$. Meanwhile, the sequence of their median densities in the beds corresponded to this order with a slightly high number in the control: $0.710^{6} \mathrm{CFU} . \mathrm{g}^{-1}(P$.

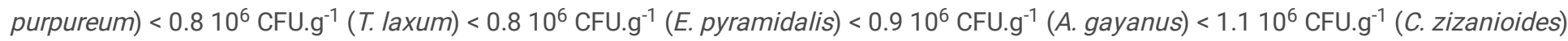
$<1.310^{6}$ CFU.g ${ }^{-1}$ (Unplanted).

To better insights the biological activity in the beds, the total bacteria density was assessed during the treatment trial (Figure 3 ). In fact, the total bacteria density oscillated between $2.910^{6}$ and $12.310^{6} \mathrm{CFU} . \mathrm{g}^{-1}$ whatever the bed, while the median density of the bed planted with $P$. purpureum was obviously the highest and the control the lowest as already demonstrated above (i.e., $8.410^{6} \mathrm{CFU}^{-1} \mathrm{~g}^{-1}(P$. purpureum$)>7.1$

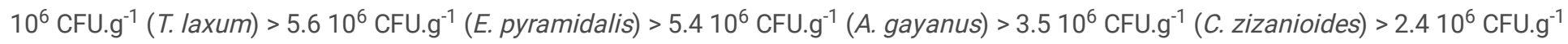
(Control)). Finally, the total bacteria density of the planted beds was significantly higher than that obtained in the control, whereas among the planted beds, the total bacteria density of $C$. zizanioides bed remained significantly lower than the other's (Mann Whitney test: $\mathrm{p}<0.05$ ).

To better understand the bacteria evolution within all the bed sediments, the vertical distribution of aerobic, anaerobic and total bacteria densities in the different sediment layers was investigated. Indeed, the figures 4, 5 and 6 showed the aerobic, anaerobic and total bacteria

Page 5/18 
densities distributions, respectively. Overall, from the upper layer [0; $10 \mathrm{~cm}]$ to the bottom layer [50; $60 \mathrm{~cm}]$ of the beds, the number of aerobic bacteria decreased ( $17.410^{6}$ to $\left.0.110^{6} \mathrm{CFU} . \mathrm{g}^{-1}\right)$ (Figure 4), while that of anaerobic bacteria increased $\left(0.110^{6}\right.$ to $\left.2.110^{6} \mathrm{CFU} . \mathrm{g}^{-1}\right)$ (Figure 5). However, the total bacteria density decreased from upper surface towards the bottom of the beds (1.5 $10^{6}$ to $17.410^{6} \mathrm{CFU} . \mathrm{g}^{-1}$ ) (Figure 6). Aerobic bacteria density of beds surface layers ([0; $10 \mathrm{~cm}]$ and $[10 ; 20 \mathrm{~cm}])$ were statistically greater than those of deep layers ([40; $50 \mathrm{~cm}]$ and [50; $60 \mathrm{~cm}])$ in planted beds, while for those of the first three (3) layers ([0; $10 \mathrm{~cm}]$, [10; $20 \mathrm{~cm}]$ and [20; $30 \mathrm{~cm}])$, the bacteria densities of the planted beds were significantly higher than those of the unplanted bed. Among the planted beds, the bacteria density of $C$ zizanioides was lower than those of the other beds, excluding that of A gayanus's bed in the [20; $30 \mathrm{~cm}]$ layer (Mann Whitney test: $\mathrm{p}<$ 0.05).

Unlike the aerobic bacteria, statistical analysis showed that in all beds, the densities of the anaerobic bacteria of the two first upper layers ([0; $10 \mathrm{~cm}]$ and [10; $20 \mathrm{~cm}])$ were lower than those obtained in the two last layers ([40; $50 \mathrm{~cm}]$ and [50; $60 \mathrm{~cm}])$ (Mann Whitney test: $p<$ 0.05). Likewise, the anaerobic bacteria densities in unplanted beds were not clearly distinguished in the different consecutive layers. However, no difference was obtained between the different planted and unplanted beds (Kruskal Wallis test: $p>0.05$ ).

Like the aerobic bacteria case, the total bacteria density in the beds was significantly greater in the upper horizons ([0; $10 \mathrm{~cm}]$ and [10; 20 $\mathrm{cm}]$ ) than those of the deep layers ([40; $50 \mathrm{~cm}]$ and [50; $60 \mathrm{~cm}])$ (Mann Whitney test: $p<0.05)$. In planted beds, total bacteria density in bed planted with $C$. zizanioides was also lower, whereas those of other beds do not differ significantly. On the other hand, the total bacteria densities in the different planted beds were significantly higher than those obtained within the control in the first two upper layers ([0; 10 $\mathrm{cm}]$ and $[10 ; 20 \mathrm{~cm}])$. However, the sequence of the total bacteria densities was more important in the bed planted with $P$. purpureum, and followed by those of T. laxum, E. pyramidalis, A. gayanus, C. zizanioides, and unplanted bed.

\section{Discussion}

\subsection{Plant growth response}

The biomasses developed by E. pyramidalis, P. purpureum and T. laxum were significantly higher than those of $A$. gayanus and $C$. zizanioides due to a favorable adaptation of these plants to the substrate provided. This result could be explained by the quality of waters rich in nitrogen, phosphorus and various salts (Dotro et al. 2017). Some authors such as Kengne et al. (2014) and Ouattara et al. (2008) confirmed this assumption based on quality of nutrients provided, as is the case of the synthetic domestic wastewater used in this study, which provides the nutrients necessary for their good growth. Among the five species studied, $P$. purpureum produced not only the most abundant biomass $\left(15.2 \mathrm{~kg} \cdot \mathrm{m}^{-2}\right)$, but also the largest diameter stump $(21.3 \mathrm{~cm})$. This result could be attributed to the ecological conditions and an adaptation more favorable to the growth of this plant. With the same plant, Pillai and Vijayan (2013) obtained also a large biomass production (i.e., $20-25 \mathrm{~kg} . \mathrm{m}^{-2}$ ) in a vertical flow constructed wetland using raw greywater.

\subsection{CWs performance}

The increase of $\mathrm{pH}$ and dissolved oxygen (DO) at the beds' outlet compared to raw wastewater could be due to the consequence of the biodegradation of organic matter and/or the metabolism of nutrient assimilation by plant in the CWs (Koné et al. 2011). In fact, the absorption of nitrate ions through the roots of the plant is countercurrent to a transport of hydroxide ions ( $\left.\mathrm{HO}^{-}\right)$from the plant to the outside or a co-transport of hydronium ions $\left(\mathrm{H}_{3} \mathrm{O}^{+}\right.$or $\left.\mathrm{H}^{+}\right)$within plant cells (Wegner, 2017). Hence, the release of the $\mathrm{OH}^{-}$ions in the medium during this process would also raise the $\mathrm{pH}$ of the bed filtrates. However, the high $\mathrm{pH}$ of the uncultivated bed compared to the planted beds could be due to the fact that the $\mathrm{CO}_{2}$ resulting from the biodegradation of organic matter acidifies the medium in the presence of water, which could put back into solution the calcium and magnesium hydrogen carbonate content in the synthetic wastewater, adsorbed partly in the substrates. Therefore, the mineralization of these compounds would be increased the $\mathrm{pH}$ of the medium within unplanted beds. Finally, the difference of $\mathrm{pH}$ observed between the planted beds is due to the physiological specificities of the plants used. On the other hand, the increase of OD in the bed filtrates would result from the aeration of the raw water during its application to the beds of the vertical flow wetlands and the oxygen released at the apex of the rootlets of the plants (Pérez et al. 2014).

The volume of water collected outlet the CWs beds was lower than the volume of wastewater applied, regardless of the beds considered. According to Kadlec and Wallace (2009), this result is related to evaporation phenomena on the bed and evapotranspiration of plants, as well as the retention of a fraction of water in the bed sediments. Moreover, the difference of water volume between the planted beds is due to actual needs of each plant and the absence of plant within the control would increase the rejection of greater water volume in this unplanted bed compared to those planted. 
Concerning the pollutants $\left(\mathrm{COD}, \mathrm{BOD}_{5}, \mathrm{TN}, \mathrm{NH}_{4}{ }^{+}, \mathrm{NO}_{3}{ }^{-}\right.$and $\left.\mathrm{PO}_{4}{ }^{3-}\right)$, high removal efficiencies were obtained within the bed filtrates, excluding $\mathrm{NO}_{3}{ }^{-}$, probably due to the type of wetland used in this study. Indeed, the type of vertical flow wetland used would favor aerobic and sedimentation and/or filtration mechanisms, which are the main removal mechanisms of theses pollutants in presence of the plants, whereas the degradation of $\mathrm{NO}_{3}{ }^{-}$would need an anaerobic environment by appropriate organisms such as anaerobic bacteria (Norton 2014).

In fact, this type of system requires an intermittent feed of the wastewater, thus leading a higher recharge of the bulk of oxygen used for the metabolism of the bacteria during the biodegradation of these pollutants. In addition, lagoon sand of uniform particle size used in this study as sediment of the beds favor sedimentation and/or filtration mechanisms of the pollutant particles of the wastewater during the crossing of the bed sediments (Kadlec and Wallace 2009).

The improvement of removal efficiencies within the planted beds could be explained by the stimulating effect of the plants on degradation processes of the organic ( $\mathrm{COD}$ and $\left.\mathrm{BOD}_{5}\right)$ and nutrient $\left(\mathrm{TN}, \mathrm{NH}_{4}{ }^{+}\right.$, and $\left.\mathrm{PO}_{4}{ }^{3-}\right)$ pollutants through the secretion of root exudates $($ Weber and Gagnon 2014). In addition, the other removal pathways as the assimilation by macrophytes, the precipitation or the dissolution, and the adsorption in the sediment, would also contribute to further reduction of these compounds in planted beds (Vymazal 2007; Norton, 2014).

Moreover, the beds with P. purpureum and T. laxum were more efficient than those of E. pyramidalis, A. gayanus and C. zizanioides due, on the one hand, to their plant biomass (i.e., $15.2 \mathrm{~kg} \cdot \mathrm{m}^{-2}$ for P. purpureum and $13.1 \mathrm{~kg} \cdot \mathrm{m}^{-2}$ for T. laxum against $8.3 \mathrm{~kg} . \mathrm{m}^{-2}$ for $E$. pyramidalis, $2.6 \mathrm{~kg} . \mathrm{m}^{-2}$ for $A$. gayanus and $1.8 \mathrm{~kg} . \mathrm{m}^{-2}$ for C. zizanioides) and stumps developed (i.e., $21.3 \mathrm{~cm}$ for $P$. purpureum, $16.4 \mathrm{~cm}$ for $T$. laxum against $12.1 \mathrm{~cm}$ for E. pyramidalis, $10.7 \mathrm{~cm}$ for $C$. zizanioides and $8.7 \mathrm{~cm}$ for $A$. gayanus), and on the other hand, their secretion of root exudates (Stottmeister et al. 2003; Vymazal 2007). Then, their large stumps and abundance of their plant cover would create a microclimate favoring a high proliferation of purifying organisms (macro and micro-organisms) improving the treatment, thus underscoring $66.8 \%$ and $24.3 \%$ of nitrate reductions from wastewater with $P$. purpureum and T. laxum, respectively. A removal of nitrate (88\%) in a vertical flow constructed wetlands with P. purpureum using greywater was also observed by Pillai and Vijayan (2013). According to Koné et al. (2011), the reduction of $\mathrm{NO}_{3}{ }^{-}$in the $\mathrm{CWs}$ filtrates could also be explained by an enough quantity of carbon available after the removal of the COD, which would favor a high denitrification of nitrogen by heterotrophic bacteria.

\subsection{Bacterial density in CWs}

The high aerobic bacteria density relative to anaerobic bacteria in all the CWs beds, excluding unplanted beds could be related to the favorable conditions of proliferation of microbial communities created by planted wetlands vegetation. According to Dotro et al. (2017) and Wang et al. (2018), plants improve the oxygenation of the rhizosphere by the transfer of atmospheric oxygen to the root zone, which would promote the metabolism (i.e., secreting exudates) and growth of bacteria aerobic, thus favoring microbial activity in the sediment of planted beds. Thus, macrophytes living in CWs morphologically adapt by allowing the transport of oxygen to the root system thanks to large cavities inside the stems and rhizomes (Zhai et al. 2013; Weber and Gagnon 2014).

In the case of this study, the bacterial densities obtained (from 2.9 to $12.310^{6} \mathrm{CFU} . \mathrm{g}^{-1}$ ) was higher than those reported by Hatano et al. (1993) $\left(2.710^{6} \mathrm{CFU}^{-1}\right)$ and less than those of Münch et al. (2005) (3.2 10 ${ }^{9} \mathrm{CFU}^{-1}$ ) in planted beds and (2.5 $\left.10^{8} \mathrm{CFU} . \mathrm{g}^{-1}\right)$ in unplanted beds. This difference could be explained by the different species of plants used, the operation mode and the type of wetlands. For instance, the high bacterial density in the bed planted with P. purpureum compared to other planted beds would depend on its large above-ground biomass and stump diameter developed (Gagnon et al. 2007). Furthermore, the trend of total bacterial density of the planted beds follow those of aerobic bacterial due to the low anaerobic bacterial density, thus showing the predominance of aerobic conditions in the planted bed sediment related to the type of vertical flow CW used.

In fact, the investigation of bacterial distribution in the bed sediment showed that the number of aerobic bacteria decreased (17.4 $10^{6}$ to 0.1 $\left.10^{6} \mathrm{CFU} . \mathrm{g}^{-1}\right)$, while that of anaerobic bacteria increased $\left(0.110^{6}\right.$ to $\left.2.110^{6} \mathrm{CFU} . \mathrm{g}^{-1}\right)$ from the upper layer $(0-10 \mathrm{~cm})$ to the bottom layer $(-50$ $60 \mathrm{~cm}$ ) of the beds. This result could be related to the reduction of the amount of oxygen in the bed sediment, from the surface to the bottom. Indeed, the upper layers of the beds being more aerated (Münch et al. 2005), the aerobic bacteria there develop more favorably and swarm with respect to the anaerobic bacteria. On the other hand, in the bottom layer oxygenation is relatively low, which would further promote the growth of anaerobic bacteria. However, the trend of total bacteria has shown that aerobic bacteria dominate within it.

The significant differences in aerobic bacteria density between the first two layers and that of the bottom in planted beds, and between the first three surface layer and that of the bottom in unplanted bed could be explained by the abundant roots and macroinvertebrates in the surface layers, whose their activities would further aerate the superficial layers of the wetland (Ouattara et al. 2009, 2011). Moreover, the 
difference of bacteria density observed between the planted beds is due to from the morphology of the different plants in the wetlands. Indeed, we note that the sequence of the density of the aerobic bacteria of the wetlands ( $P$. purpureum $>T$. laxum $>$ E. pyramidalis $>A$. gayanus $>C$. zizanioides) is relatively like that of the biomasses and plant stumps. Thus, these plant biomasses would have, depending on their importance, promoted a significant oxygenation of wetlands. This would justify the opposite sequences of anaerobic bacteria in planted beds and the fewest aerobic bacteria in unplanted bed.

\section{Conclusion}

The bacterial community investigated in CWs beds was dominated by aerobic bacteria. This study confirmed the positive influence of plants on constructed wetlands performance, through the improvement of the bacterial density and removal efficiencies in the system (i.e., yield from 5.9 to $24.1 \%$ ). However, few anaerobic bacteria were counted in the different wetlands, but were unable to reduce $\mathrm{NO}_{3}{ }^{-}$outlet of them, except for wetlands planted with $T$. laxum and P. purpureum. Besides, the number of aerobic bacteria obtained decreased (17.4 $10^{6}$ to $\left.0.110^{6} \mathrm{CFU} . \mathrm{g}^{-1}\right)$ in the wetlands, while that of anaerobic bacteria increased $\left(0.110^{6}\right.$ to $\left.2.110^{6} \mathrm{CFU} . \mathrm{g}^{-1}\right)$, from the upper to the bottom layers. Since $P$ purpureum promotes the best performance, CWs with this type of plant could be a cost-effective alternative method of wastewater treatment.

\section{Declarations}

\section{Funding}

Not applicable

\section{Conflicts of interest/Competing interests}

Not applicable

\section{Availability of data and material}

Not applicable

\section{Code availability}

Not applicable

\section{Authors' contributions}

All authors contributed to the study conception and design. [Franck Michaël Zahui] and [Jean-Marie Pétémanagnan Ouattara] carried out the experiment trial, collected field data and processed data. The first draft of the manuscript was written by [Franck Michaël Zahui] and all authors commented on previous versions of the manuscript. All authors read and approved the final manuscript.

\section{Ethics approval}

Not applicable

\section{Consent to participate}

I voluntarily agree to answer any question relating to this research in order to work for the success of its publication in your journal (Wetlands Ecology and Management).

\section{Consent for publication}

I give my consent for article to be published in your journal (Wetlands Ecology and Management)

I understand that the text and any pictures published in the article will be freely available on the internet and may be seen by the general public.

\section{Acknowledgments}


This study has benefited from the technical support of the Laboratory of National of Testing, Quality, Metrology and Analysis of Cote d'Ivoire. The authors also deeply appreciate the valuable contributions of Dr. YEO Napari Elysée in obtaining the products of analysis and preparation of synthetic wastewater. We do not forget the late Mr. ASSI Yapo Jean from National Center of Floristic (NCF-Abidjan) and Dr. KOUADJA Gouagoua Séverin from National Center of Agronomic Research (NCAR-Bouaké), for their contribution in the selection of the tested plant species.

\section{References}

1. Alexandros S, Akratos S (2016) Removal of Pathogenic Bacteria in Constructed Wetlands: Mechanisms and Efficiency. In: Ansari, A., Gill, S., Gill, R., Lanza, G., Newman, L. (Eds.). Phytoremediation, 4:327-346

2. Choudhary AK, Kumar S, Sharma K (2011) Constructed wetlands: An approach for waste-water treatment. Elixir Pollution 37:666-3672

3. Coulibaly L, Kouakou J, Savané I, Gourène G (2008a) Domestic wastewater treatment with a vertical completely drained pilot scale constructed wetland planted with Amaranthus hybridus. Afr J Biotechnol 7:2656-2664

4. Coulibaly L, Savané I, Gourene G (2008b) Domestic wastewater treatment with a vertical completely drained pilot scale constructed wetland planted with Corchorus oliterius. Afr J Agric Res 3:587-596.

5. Dotro G, Langergraber G, Molle P, Nivala J, Puigagut J, Stein OR, von Sperling M (2017) Treatment Wetlands, 1st ed.; IWA Publishing: London, https://doi.org/10.2166/9781780408774

6. Gagnon V, Chazarenc F, Comeau Y, Brisson J (2007) Influence of macrophyte species on microbial density and activity in constructed wetlands. Water Sci Technol 56:249-254. https://doi.org/10.2166/wst.2007.510

7. Hatano K, Trettin CC, House CH, Wollum II AG (1993) Microbial populations and decomposition activity in three subsurface flow constructed wetlands. In: Moshiri, G.A. (Ed.), Constructed Wetlands for Water Quality Improvement. Lewis Publishers, London, pp 541547

8. Healy MG, Burke P, Rodgers M (2010) The use of laboratory sand, soil and crushed-glass filter columns for polishing domestic-strength synthetic wastewater that has undergone secondary treatment. J Environ Sci Heal 45:1635-1641.

http://doi.org/10.1080/10934529.2010.506130

9. Ihaka R, Gentleman R (1996) R: a language for data analysis and graphics. J Comput Graph Stat 5-299-314. https://doi.org/ $10.2307 / 1390807$

10. ISO (1984) International Standardization Organization (ISO) 5663: Water quality-Determination of Kjedahl nitrogen -Method after mineralization with selenium. $1^{\text {st }}$ Edition

11. ISO (1984) International Standardization Organization (ISO) 7150/1: Water quality-Determination of ammonium- Part 1 Manual spectrometric method $1^{\text {st }}$ Edition

12. ISO (1988) International Standardization Organization (ISO) 7890/3: Water quality- Determination of nitrate - Part 3: Spectrometric method using sulfosalicylic acid, $1^{\text {st }}$ Edition

13. ISO (1989) International Standardization Organization (ISO) 6060/2: Water quality-Determination of chemical oxygen demandPotassium dichromate method, $2^{\text {nd }}$ Edition

14. ISO (1999) International Standardization Organization (ISO) 6222: Water quality - Enumeration of culturable micro-organisms-Colony count by inoculation in a nutrient agar culture medium, $2^{\text {nd }}$ Edition

15. ISO (2003) International Standardization Organization (ISO) 5815: Water quality - Determination of biochemical oxygen demand after n days (BODn) - Part 1: Dilution and seeding method with allylthiourea addition, $1^{\text {st }}$ Edition

16. ISO (2004) International Standardization Organization (ISO) 6878: Water quality-Determination of phosphorus - ammonium molybdate spectrometric method, $2^{\text {nd }}$ Edition

17. ISO (2008) International Standardization Organization (ISO) 10523: Water quality- Determination of pH-Analytical measurement, $2^{\text {nd }}$ Edition

18. ISO (2012) International Standardization Organization (ISO) 5814: Water quality- Determination of dissolved oxygen - Electrochemical probe method, $3^{\text {rd }}$ Edition

19. Kadlec R, Wallace S (2009) Treatment wetlands. 2nd edition, CRC Press: Taylor \& Francis, Group: Boca Raton, Florida, United States

20. Kengne ES, Kengne IM, Nzouebet WAL, Akoa A, Hung NV, Strande L (2014) Performance of vertical flow constructed wetlands for faecal sludge drying bed leachate: Effect of hydraulic loading. Ecol Eng 71:384-393. http://doi.org/10.1016/j.ecoleng.2014.07.041 
21. Koné M, Zongo I, Bonou L, Koulidiati J, Joly $\mathrm{P}$, Bouvet $Y$, Sodre S (2011) Traitement d'eaux résiduaires urbaines par filtres plantés à flux vertical sous climat Soudano-Sahélien. Int J Biol Chem Sci 5:217-231. http://doi.org/10.4314/ijbcs.v5i1.68100

22. Mander U, Lõhmus K, Teiter S, Nurk K, Mauring T, Augustin J (2005) Gaseous Fluxes from Subsurface Flow Constructed Wetlands for Wastewater Treatment. J Environ Sci Heal 40:1215-1226. https://doi.org/10.1081/ESE-200055662

23. Metcalf A, Eddy MS (1991) Wastewater Engineering: Treatment, Disposal and Reuse, 3 Eds, revised by Tchobanoglous G. Burton F.L., New York

24. Münch C, Kuschk P, Roske I (2005) Root stimulated nitrogen removal: only a local effect or important for water treatment? Water Sci Technol 51:85-192. https://doi.org/10.2166/wst.2005.0316

25. Nivala J, Wallace S, Headley T (2013) Oxygen transfer and consumption in subsurface flow treatment wetlands. Ecol Eng 61:544-554. https://doi.org/10.1016/j.ecoleng.2012.08.028

26. Norton S (2014) Removal mechanisms in constructed wastewater wetlands. http://Home.Eng.lasta te.Edu/Tge/Ce421 -521/Steph en. Accessed Dec 2018

27. Oehl F, Frossard E, Fliessbach A, Dubois D, Oberson A (2004) Basal organic phosphorus mineralization in soils under different farming systems. Soil Biol Biochem 36:667-675. https://doi.org/10.1016/j.soilbio.2003.12.010

28. Ouattara PJ-M, Coulibaly L, Manizan P, Gourène G (2008) Traitement des eaux résiduaires urbaines par un marais artificiel à drainage vertical planté avec Panicum maximum sous climat tropical. Eur J Sci Res 23-25-40.

29. Ouattara PJ-M, Coulibaly L, Tiho S, Gourene G (2009) Comparison of macrofauna communities in sediments of the beds of vertical flow constructed wetlands planted with Panicum maximum (Jacq.) treating domestic wastewater. Ecol Eng 35:1237-1242. https://doi.org/10.1016/j.ecoleng.2009.05.007

30. Ouattara PJ-M, Coulibaly L, Tiho S, Ouattara A, Gourene G (2011) Panicum maximum (Jacq.) density effect upon macrofauna structure in sediments of pilot-scale vertical flow constructed wetlands treating domestic wastewater. Ecol Eng 37:217-223. https://doi.org/10.1016/j.ecoleng.2010.10.002

31. Pérez MM, Hernández JM, Bossens J, Jiménez T, Rosa E, Tack F (2014) Vertical flow constructed wetlands: kinetics of nutrient and organic matter removal. Water Sci Technol 70:76-81. https://doi.org/10.2166/wst.2014.183

32. Pillai JS, Vijayan N (2013) Wastewater Treatment: An Ecological Sanitation Approach in a Constructed Wetland. International Journal of Innovative. Int J Innov Res Sci Eng Technol 2:5193-5204.

33. Puigagut J, Salvadó H, García D, Granes F, García J (2007) Comparison of microfauna communities in full scale subsurface flow constructed wetlands used as secondary and tertiary treatment. Water Res 41:1645-1652.

https://doi.org/10.1016/j.watres.2007.01.036

34. Richardson AE, Simpson RJ (2011) Soil microorganisms mediating phosphorus availability. Plant Physiol 156:989-996. https://doi.org/10.1104/pp.111.175448

35. Rodgers M, Lambe A, Xiao L (2006) Carbon and nitrogen removal using a novel horizontal flow biofilm system. Process Biochem 41:2270-2275. https://doi.org/10.1016/j.procbio.2006.05.019

36. Sirianuntapiboon S, Jitvimolnimit S (2007) Effect of plantation pattern on the efficiency of subsurface flow constructed wetland (sfcw) for sewage treatment. Afr J Agric Res 2:447-454.

37. Stottmeister U, Wiener A, Kuschk P, Kappelmeyer U, Kästner M, Bederski O, Müller RA Moormann H (2003) Effects of plants and microorganisms in constructed wetlands for wastewater treatment. Biotechnol Adv 22:93-117. https://doi.org/10.1016/j.biotechadv.2003.08.010

38. Tao W, Hall KJ, Duff SB (2007) Microbial biomass and heterotrophic production of surface flow mesocosm wetlands treating woodwaste leachate: responses to hydraulic and organic loading and relations with mass reduction. Ecol Eng 31:132-139. https://doi.org/10.1016/j.ecoleng.2007.06.007

39. Truu M, Juhanson J, Truu J (2009) Microbial biomass, activity and community composition in constructed wetlands. Sci Total Environ 407:3958-3971. https://doi.org/10.1016/j.scitotenv.2008.11.036

40. Vymazal J (2007) Removal of nutrients in various types of constructed wetlands. Sci Total Environ 380:48-65. https://doi.org/10.1016/j.scitotenv.2006.09.014

41. Vymazal J (2010) Constructed wetlands for wastewater treatment. Water 2:530-549. https://doi.org/10.3390/w2030530

42. Wang Q, Xie H, Ngo HH, Guo W, Zhang J, Liu C, Liang S, Hu Z, Yang Z, Zhao C (2016) Microbial abundance and community in subsurface flow constructed wetland microcosms: role of plant presence. Environ Sci Pollut Res 23:4036-4045.

https://doi.org/10.1007/s11356-015-4286-0

Page 10/18 
43. Wang Q, Hu Y, Xie H, Yang Z (2018) Constructed Wetlands: A Review on the Role of Radial Oxygen Loss in the Rhizosphere by Macrophytes. Water 10:1-11. https://doi.org/10.3390/w10060678

44. Weber K P, Gagnon V (2014) Microbiology in treatment wetlands. Sustainable Sanit. Pract. Outcomes UFZ Wetland Workshop 18:25-30

45. Wegner LH (2017) Cotransport of water and solutes in plant membranes: The molecular basis, and physiological functions. AIMS Biophys 4:192-209. https://doi.org/10.3934/biophy.2017.2.192

46. Wu H, Zhang J, Li P, Zhang J, Xie H, Zhang B (2011) Nutrient removal in constructed microcosm wetlands for treating polluted river water in northern China. Ecol Eng 37:560-568. https://doi.org/10.1016/j.ecoleng.2010.11.020

47. Wu H, Zhang J, Wei R, Liang S, Li C, Xie H (2013) Nitrogen transformations and balance in constructed wetlands for slightly polluted river water treatment using different macrophytes. Environ Sci Pollut Res 20:443-451. https://doi.org/10.1007/s11356-012-0996-8

48. Zhai X, Piwpuan N, Arias CA, Headley T, Brix H (2013) Can root exudates from emergent wetland plants fuel denitrification in subsurface flow constructed wetland systems? Ecol Eng 61:555-563. https://doi.org/10.1016/j.ecoleng.2013.02.014

\section{Tables}

Table 1. Chemicals used for synthetic wastewater composition.

\begin{tabular}{|ll|}
\hline Chemicals & Concentration $\left(\mathbf{m g . L ^ { - 1 }}\right)$ \\
\hline Glucose & 200 \\
\hline Starch & 200 \\
\hline Yeast & 40 \\
\hline Milk powder & 120 \\
\hline Urea & 30 \\
\hline $\mathrm{NH}_{4} \mathrm{Cl}^{-10}$ & 70 \\
\hline $\mathrm{KH}_{2} \mathrm{PO}_{4}$ & 80 \\
\hline $\mathrm{NaHCO}_{3}$ & 200 \\
\hline $\mathrm{MgSO}_{4} ; 7 \mathrm{H}_{2} \mathrm{O}$ & 50 \\
\hline $\mathrm{FeSO}_{4} ; 7 \mathrm{H}_{2} \mathrm{O}$ & 2 \\
\hline $\mathrm{MnSO}_{4} ; \mathrm{H}_{2} \mathrm{O}$ & 2 \\
\hline $\mathrm{CaCl}_{2} ; 6 \mathrm{H}_{2} \mathrm{O}$ & 3 \\
\hline $\mathrm{Bentonite}^{2}$ & 60 \\
\hline
\end{tabular}

Table 2. Means and standard deviations of plant above-ground biomass and stump diameter of different plant species.

\begin{tabular}{|lll|}
\hline & Above-ground Biomass $\left(\mathrm{kg} \cdot \mathrm{m}^{-2}\right)$ & Stumps diameter $(\mathrm{cm})$ \\
\hline A. gayanus & $2.6^{\mathrm{a}} \pm 1.8$ & $8.6^{\mathrm{a}} \pm 3.6$ \\
\hline C. zizanioides & $1.8^{\mathrm{a}} \pm 0.7$ & $10.7^{\mathrm{a}} \pm 4.2$ \\
\hline E. pyramidalis & $8.3^{\mathrm{b}} \pm 4.6$ & $12.1^{\mathrm{a}} \pm 5.5$ \\
\hline P. purpureum & $15.2^{\mathrm{b}} \pm 0.7$ & $21.3^{\mathrm{a}} \pm 9.5$ \\
\hline T. laxum & $13.1^{\mathrm{b}} \pm 2.3$ & $16.4^{\mathrm{a}} \pm 6.7$ \\
\hline
\end{tabular}

Values within the same column followed by the same superscript letter (i.e. a, b) are not significantly different at $p<0.05$

Page $11 / 18$ 
Table 3. Means and standard deviations of $\mathrm{pH}$, dissolved oxygen (DO) and volume of water within inlet and outlet of the beds using different plant species.

\begin{tabular}{|c|c|c|c|c|c|c|c|}
\hline \multirow[t]{3}{*}{ Parameters } & \multirow{3}{*}{$\begin{array}{l}\text { Inlet } \\
\text { Wastewater }\end{array}$} & \multicolumn{6}{|l|}{ Outlet } \\
\hline & & $T$ & A. & C. zizanioides & E. pyramidalis & P. purpureum & Unplanted \\
\hline & & laxum & gayanus & & & & \\
\hline $\mathrm{pH}$ & $6.81 \pm 0.1^{\mathrm{a}}$ & $7.17^{\mathrm{cb}} \pm 0.3$ & $6.92^{\mathrm{a}} \pm 0.3$ & $7.05^{\mathrm{c}} \pm 0.3$ & $6.93^{\mathrm{a}} \pm 0.3$ & $7.06^{\mathrm{c}} \pm 0.2$ & $7.33^{b} \pm 0.3$ \\
\hline $\mathrm{DO}\left(\mathrm{mg} \cdot \mathrm{L}^{-1}\right)$ & $2.13^{a} \pm 0.6$ & $7.53^{b} \pm 1.6$ & $6.50^{C} \pm 0.8$ & $6.70^{c} \pm 1$ & $6.63^{c} \pm 1$ & $7.24^{b} \pm 1.1$ & $5.41^{d} \pm 0.9$ \\
\hline Volume (L) & $80^{\mathrm{a}}$ & $55.6^{b} \pm 3.8$ & $60.3^{c} \pm 3$ & $62.2^{d} \pm 3.6$ & $58.6^{\mathrm{e}} \pm 5.8$ & $54.2^{\mathrm{b}} \pm 4.3$ & $72.4^{f} \pm 1.9$ \\
\hline
\end{tabular}

Values within the same row followed by the same superscript letter (i.e. a, b, c ...) are not significantly different at $p<0.05$

Table 4. Average, maximum, minimum concentrations of different parameters ( $\mathrm{COD}, \mathrm{BOD}_{5}, \mathrm{TN}, \mathrm{NH}_{4}{ }^{+}, \mathrm{NO}_{3}{ }^{-}$and $\mathrm{PO}_{4}{ }^{3-}$ ) and yields within outlet of the beds using different plant species. 


\begin{tabular}{|c|c|c|c|c|c|c|c|c|c|c|c|c|c|}
\hline \multicolumn{2}{|c|}{$\begin{array}{l}\text { Treatment and } \\
\text { parameter }\end{array}$} & \multicolumn{2}{|c|}{$\begin{array}{l}\mathrm{COD}\left(\mathrm{mgO}_{2} \cdot \mathrm{L}^{-}\right. \\
\left.{ }^{-}\right)\end{array}$} & \multicolumn{2}{|c|}{$\begin{array}{l}\mathrm{BOD}_{5}\left(\mathrm{mg} \mathrm{O}_{2} \cdot \mathrm{L}^{-}\right. \\
\left.{ }^{1}\right)\end{array}$} & \multicolumn{2}{|c|}{$\mathrm{TN}\left(\mathrm{mg} \cdot \mathrm{L}^{-1}\right)$} & \multicolumn{2}{|c|}{$\mathrm{NH}_{4}^{+}\left(\mathrm{mg} \cdot \mathrm{L}^{-1}\right)$} & \multicolumn{2}{|c|}{$\mathrm{NO}_{3}^{-}\left(\mathrm{mg} \cdot \mathrm{L}^{-1}\right)$} & \multicolumn{2}{|c|}{$\mathrm{PO}_{4}{ }^{3-}\left(\mathrm{mg} \cdot \mathrm{L}^{-1}\right)$} \\
\hline & & Value & $\% R$ & Value & $\% \mathbf{R}$ & Value & $\% R$ & Value & $\% R$ & Value & $\% \mathbf{R}$ & Value & $\% R$ \\
\hline \multirow[t]{3}{*}{ Wastewater } & Average & $611.8^{a}$ & - & $369.8^{a}$ & - & $41.4^{\mathrm{a}}$ & - & $33.4^{\mathrm{a}}$ & - & $1.8^{\mathrm{a}}$ & - & $7.4^{\mathrm{a}}$ & - \\
\hline & Max & 623.3 & - & 373.8 & - & 44.5 & - & 35 & - & 2 & - & 7.9 & - \\
\hline & Min & 535 & - & 356.1 & - & 37.6 & - & 31 & - & 1.1 & - & 6.8 & - \\
\hline \multirow[t]{3}{*}{ T. laxum } & Average & $48.7^{\mathrm{bc}}$ & $94.5^{a}$ & $14.7^{b}$ & $97.2^{\mathrm{a}}$ & $11^{\mathrm{bd}}$ & $81.4^{\mathrm{ac}}$ & $9^{b c}$ & $81.3^{\mathrm{a}}$ & $1.9^{a}$ & $24.3^{\mathrm{a}}$ & $0.6^{b}$ & $\begin{array}{l}94.6 \\
\mathrm{a}\end{array}$ \\
\hline & Max & 67 & 97.2 & 19.2 & 97.9 & 17.2 & 94.9 & 14 & 94.1 & 7.5 & 96.4 & 2 & 99.9 \\
\hline & Min & 27.3 & 92.5 & 11.5 & 95.8 & 3.3 & 69.2 & 2.4 & 77.2 & 0.1 & $n$ & 0.01 & 81.7 \\
\hline \multirow[t]{3}{*}{ A. gayanus } & Average & $73.9^{b c}$ & $90.9^{b}$ & $23.3^{c}$ & $95.2^{\mathrm{b}}$ & $12.8^{\mathrm{bc}}$ & $76.3^{\mathrm{ab}}$ & $9.6^{\mathrm{bc}}$ & $78.2^{\mathrm{ab}}$ & $4.4^{b}$ & $\mathrm{n}$ & $2^{c}$ & $79.9^{b}$ \\
\hline & Max & 121.4 & 93.8 & 30.7 & 96.7 & 20.1 & 94.6 & 15.3 & 94.8 & 12.7 & 38.2 & 4.1 & 95.3 \\
\hline & Min & 52.8 & 85.6 & 16.3 & 93.4 & 3.2 & 61 & 2.3 & 75.1 & 1.2 & $\mathrm{n}$ & 0.5 & 61 \\
\hline \multirow{3}{*}{$\begin{array}{l}\text { C. } \\
\text { zizanioides }\end{array}$} & Average & $63.4^{b}$ & $91.9^{c}$ & $21.8^{c}$ & $95.4^{\mathrm{b}}$ & $13.6^{c}$ & $74.3^{b}$ & $10.2^{\mathrm{c}}$ & $76^{b}$ & $4.3^{b}$ & $n$ & $2.1^{\mathrm{c}}$ & $77.4^{b}$ \\
\hline & Max & 75.8 & 93.7 & 30.7 & 97.5 & 20.7 & 88.5 & 17.3 & 91.2 & 9.4 & 85.4 & 3.6 & 86.3 \\
\hline & Min & 53.2 & 89.8 & 11.5 & 93 & 6.2 & 57.4 & 3.6 & 72.2 & 0.3 & $\mathrm{n}$ & 1.4 & 61.1 \\
\hline \multirow{3}{*}{$\begin{array}{l}\text { E. } \\
\text { pyramidalis }\end{array}$} & Average & $55.3^{\mathrm{bc}}$ & $93.4^{d}$ & $18.4^{\mathrm{d}}$ & $96.4^{c}$ & $13.3^{\mathrm{b}}$ & $76.1^{\mathrm{b}}$ & $9.8^{\mathrm{bc}}$ & $78.4^{\mathrm{ab}}$ & $4^{b}$ & $n$ & $1.7^{\mathrm{c}}$ & $82.6^{b}$ \\
\hline & Max & 64.2 & 95.2 & 24 & 98.4 & 23.5 & 93.3 & 18.6 & 94.4 & 11.8 & 94.8 & 4.1 & 99.6 \\
\hline & Min & 39.7 & 91.2 & 7.7 & 94.2 & 3.6 & 58.3 & 2.5 & 71.3 & 0.1 & $\mathrm{n}$ & 0.04 & 62.5 \\
\hline \multirow{3}{*}{$\begin{array}{l}P . \\
\text { purpureum }\end{array}$} & Average & $36.7^{c}$ & $95.9^{\mathrm{e}}$ & $8^{e}$ & $98.5^{\mathrm{d}}$ & $9.6^{d}$ & $84^{c}$ & $7.8^{\mathrm{b}}$ & $84^{\mathrm{a}}$ & $0.8^{\mathrm{c}}$ & $66.8^{\mathrm{b}}$ & $0.3^{d}$ & $96.9^{c}$ \\
\hline & Max & 48.1 & 97 & 14.4 & 99.2 & 17.3 & 98.5 & 14.6 & 98.2 & 2.4 & 96.8 & 1.7 & 99.7 \\
\hline & Min & 28.84 & 93.5 & 4.8 & 96.8 & 1 & 70.8 & 0.7 & 75.4 & 0.1 & $n$ & 0.03 & 81 \\
\hline \multirow[t]{3}{*}{ Unplanted } & Average & $150.2^{d}$ & $77.7^{f}$ & $43.8^{f}$ & $89.3^{\mathrm{e}}$ & $19.4^{\mathrm{e}}$ & $57.3^{d}$ & $13.5^{d}$ & $63.3^{c}$ & $5.1^{\mathrm{b}}$ & $\mathrm{n}$ & $3.8^{\mathrm{e}}$ & $53.3^{d}$ \\
\hline & Max & 221.4 & 83.5 & 52.8 & 93.8 & 34.1 & 74.8 & 18.8 & 77.3 & 9 & 45 & 4.7 & 66.7 \\
\hline & Min & 110.4 & 65.5 & 25.9 & 87.2 & 12.5 & 24.4 & 8.6 & 49.1 & 0.9 & $\mathrm{n}$ & 2.8 & 45 \\
\hline
\end{tabular}

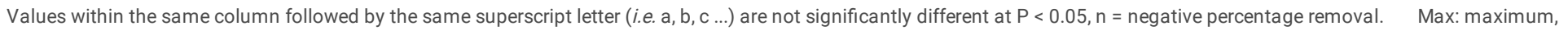
Min: minimum 


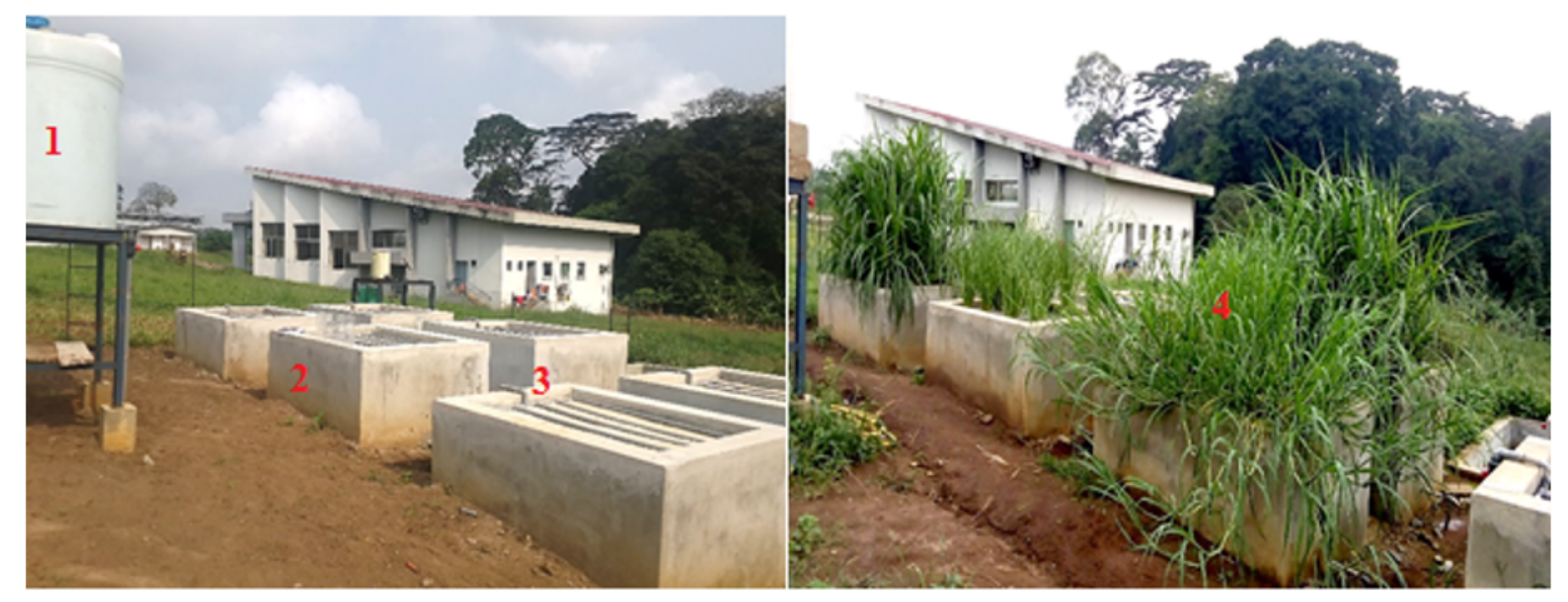

Figure 1

Experimental set-up at the pilot-scale, 1: feeding tank, 2: bed, 3: irrigation device, 4: plants growing on the beds after two months

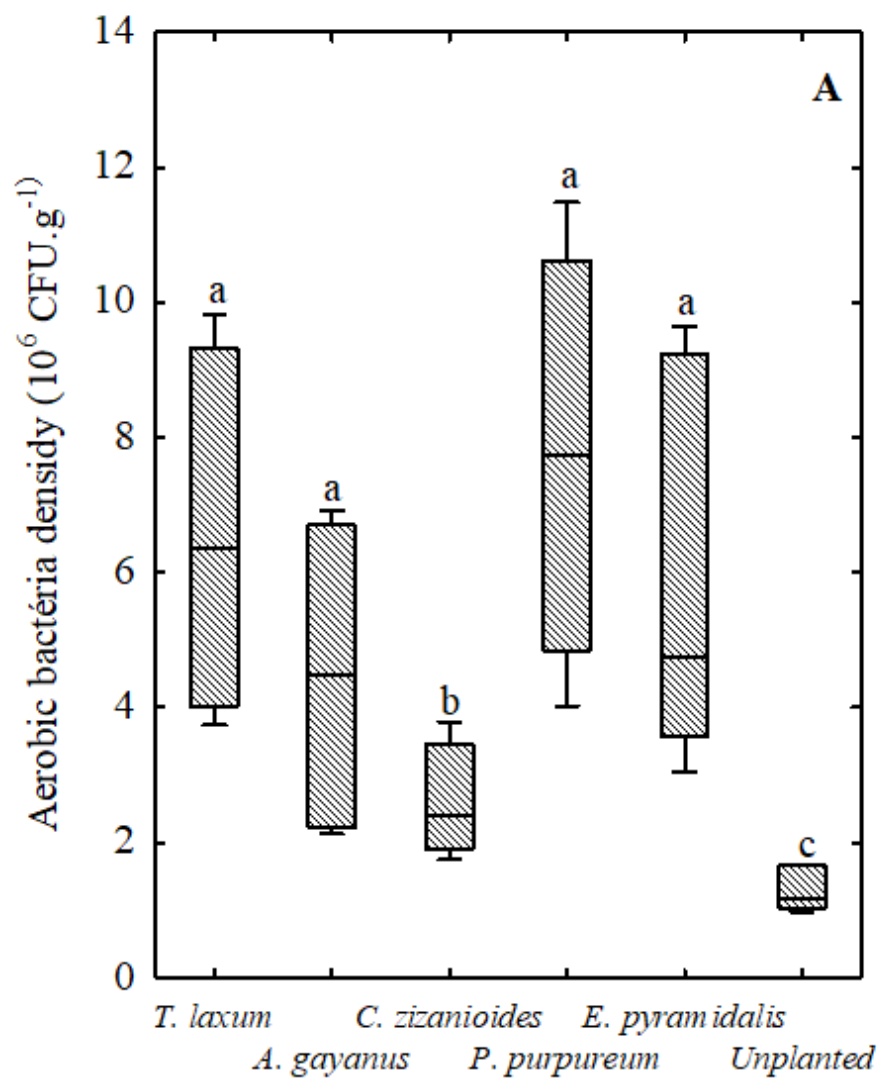

Beds of CWs

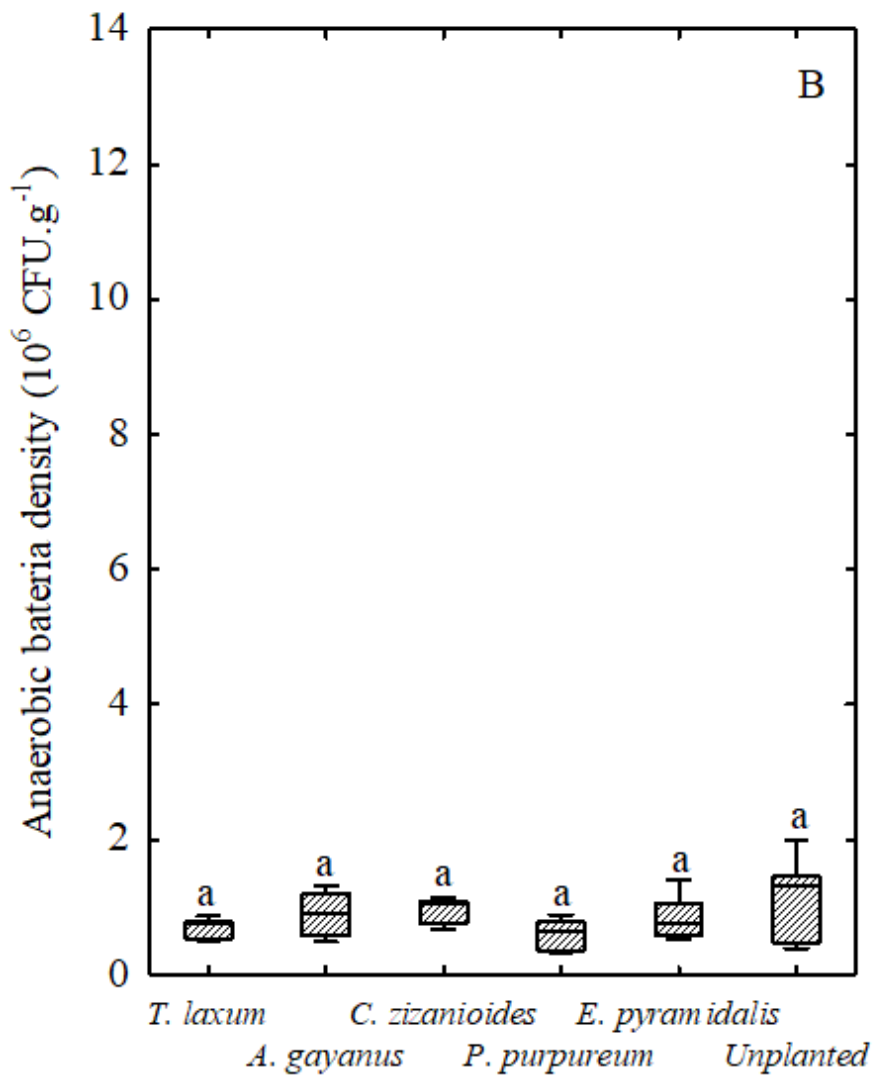

Beds of CWs

Figure 2

Variation of aerobic (A) and anaerobic (B) bacteria densities in the bed sediments at the end the treatment trial. Box-plots bearing one letter-identical are not significantly different $(p>0.05)$ 


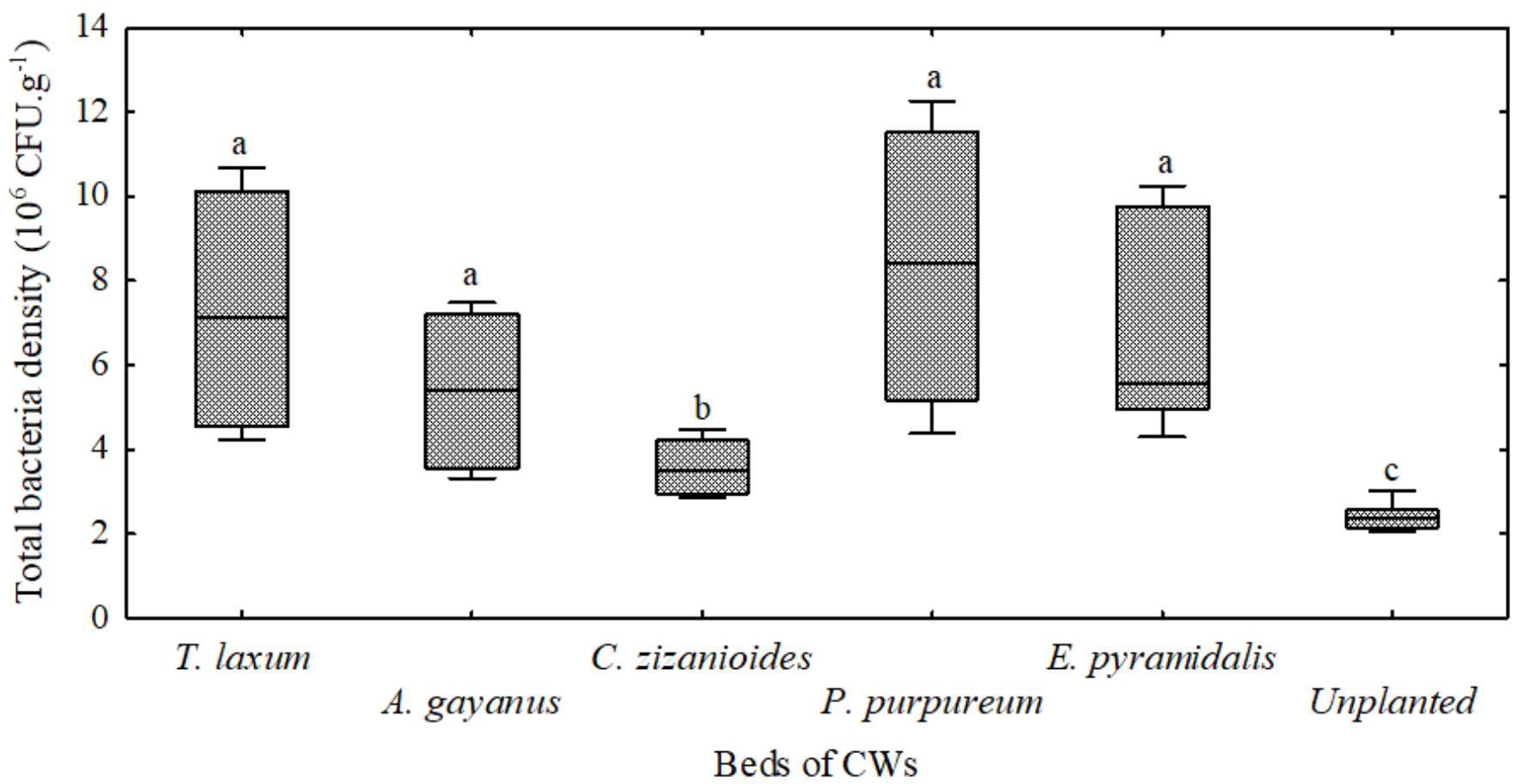

\section{Figure 3}

Variation of total bacteria density in the bed sediment at the end the treatment trial. Box-plots bearing one letter-identical are not significantly different $(p>0.05)$ 


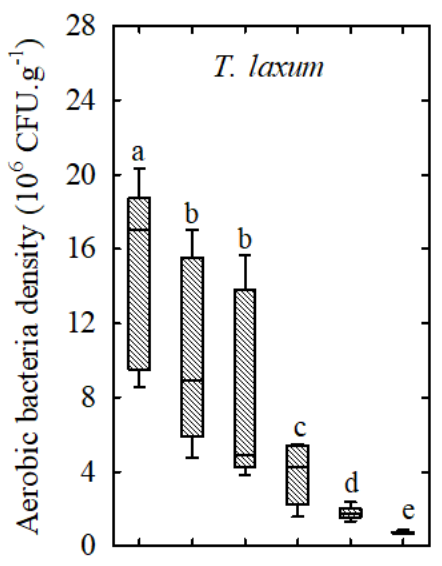

L1 L2 L3 L4 L5 L6

Layers
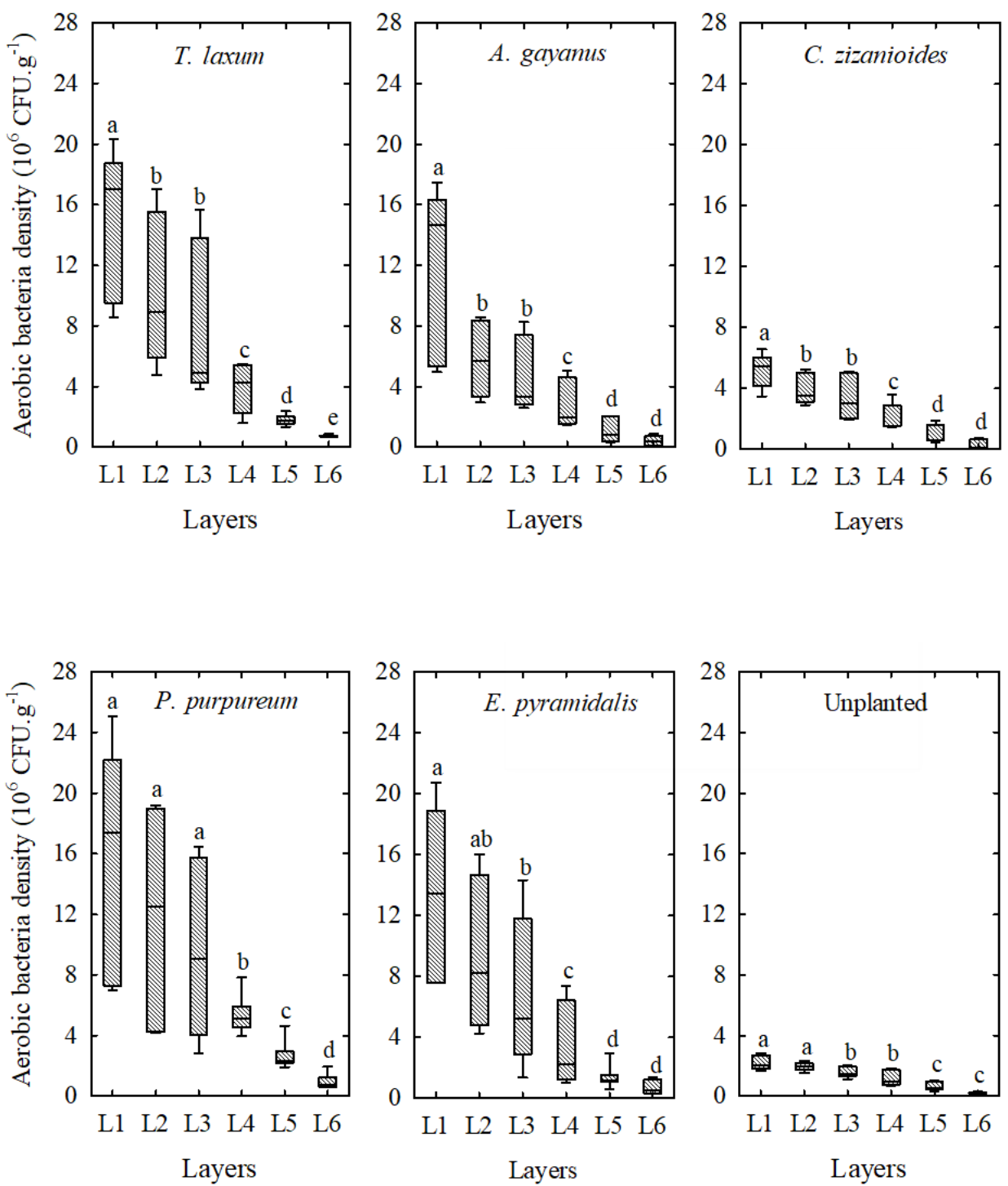

\section{Figure 4}

Vertical distribution of aerobic bacteria density in the different sediment layers of the $\mathrm{CW}$ beds from upper surface to bottom layer: $\mathrm{L} 1=$ layer [0; $10 \mathrm{~cm}], \mathrm{L} 2=$ layer [10; $20 \mathrm{~cm}], \mathrm{L} 3=$ layer [20; $30 \mathrm{~cm}], \mathrm{L} 4=$ layer [30; $40 \mathrm{~cm}], \mathrm{L} 5=$ layer [40; $50 \mathrm{~cm}]$, L6 = layer [50; $60 \mathrm{~cm}]$. Box-plots bearing at least one letter-identical are not significantly different $(p>0.05)$ 


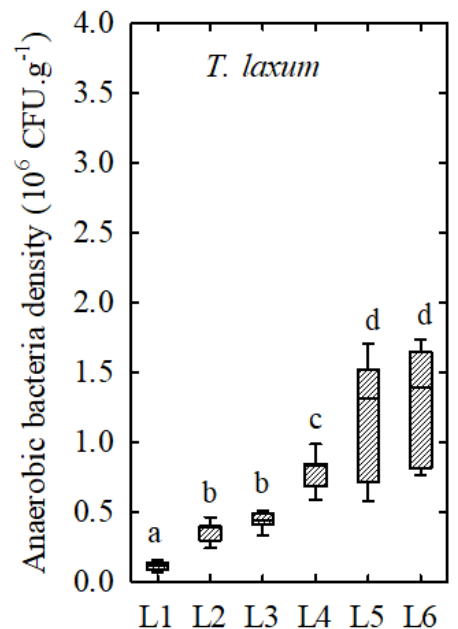

Layers

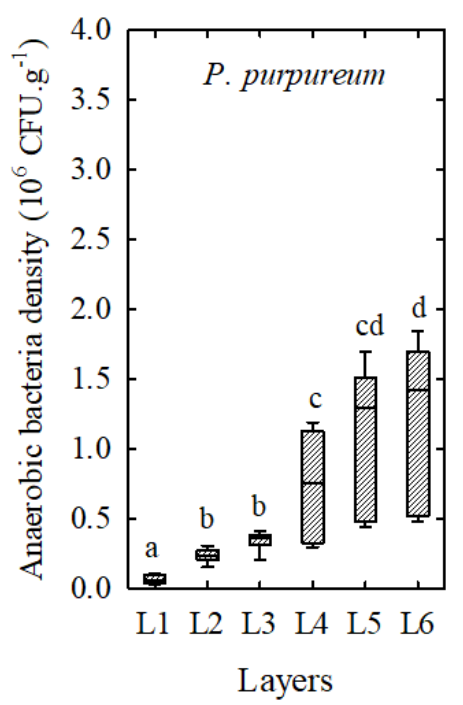

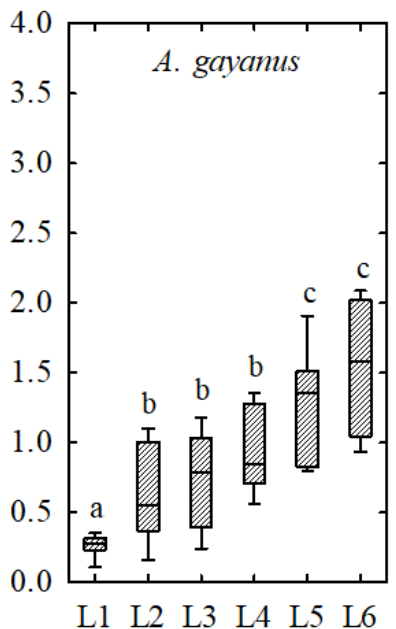

Layers
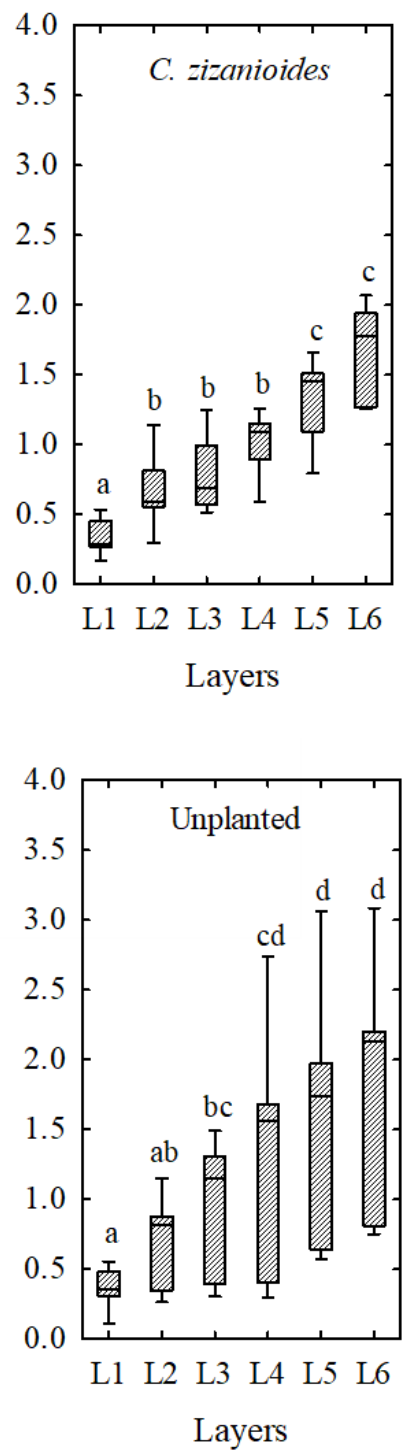

\section{Figure 5}

Vertical distribution of anaerobic bacteria density in the different sediment layers of the $\mathrm{CW}$ beds from upper surface to bottom layer: $\mathrm{L} 1=$ layer [0; $10 \mathrm{~cm}$ ], L2 = layer [10; $20 \mathrm{~cm}], \mathrm{L} 3=$ layer [20; $30 \mathrm{~cm}], \mathrm{L} 4=$ layer [30; $40 \mathrm{~cm}], \mathrm{L} 5=$ layer [40; $50 \mathrm{~cm}]$, L6 = layer [50; $60 \mathrm{~cm}]$. Box-plots bearing at least one letter-identical are not significantly different $(p>0.05)$ 

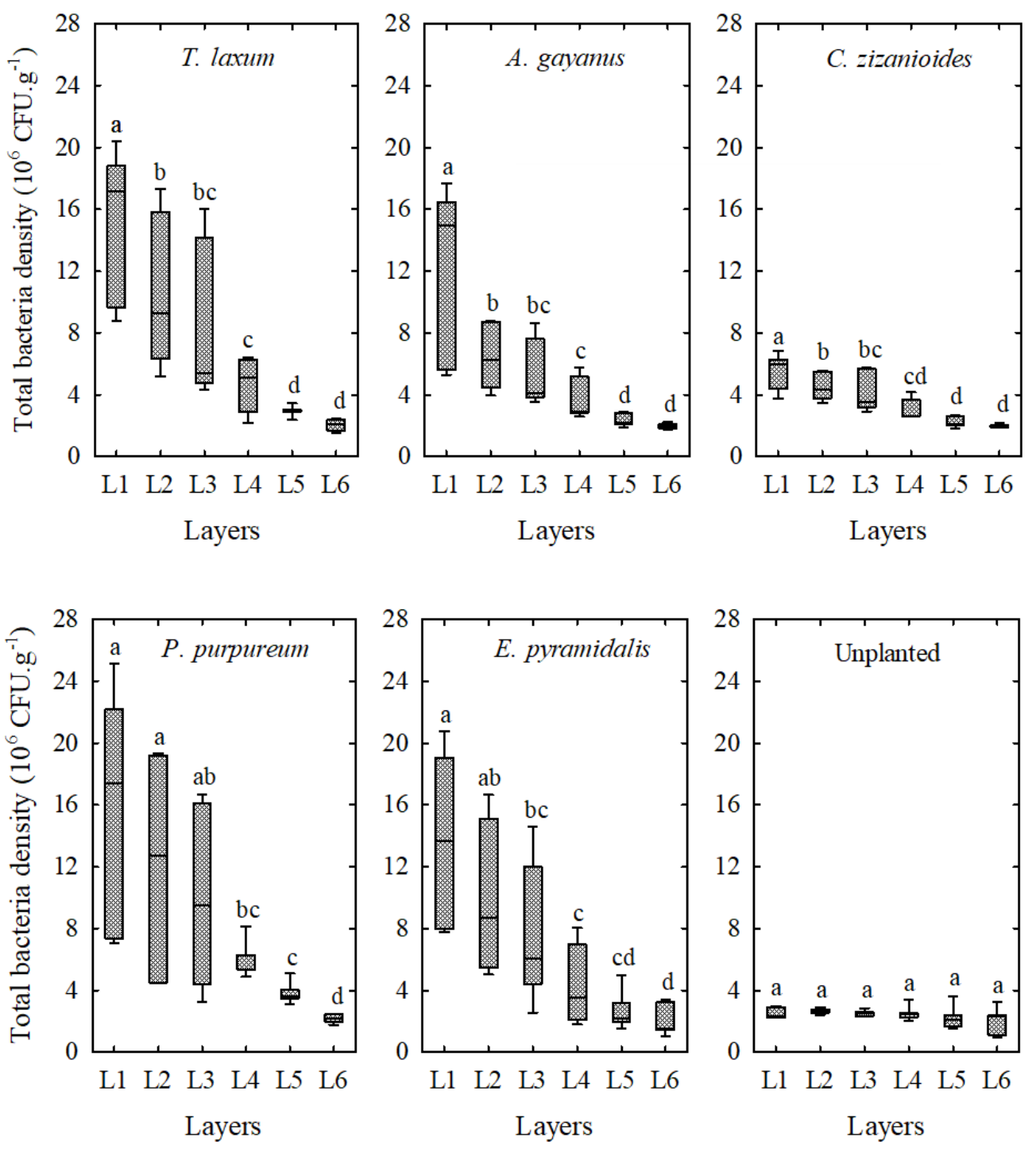

\section{Figure 6}

Vertical distribution of total bacteria density in the different sediment layers of the $\mathrm{CW}$ beds from upper surface to bottom layer: $\mathrm{L} 1=$ layer [0; $10 \mathrm{~cm}]$, L2 = layer [10; $20 \mathrm{~cm}]$, L3 = layer [20; $30 \mathrm{~cm}]$, L4 = layer [30; $40 \mathrm{~cm}]$, L5 = layer [40; $50 \mathrm{~cm}]$, L6 = layer [50; $60 \mathrm{~cm}]$. Box-plots bearing at least one letter-identical are not significantly different $(p>0.05)$ 